\title{
Use of land shares in common ownership of agricultural land (based on the materials of Sibir LLC in Yalutorovsky District of Tyumen Region)
}

\author{
Elena Evtushkova* \\ State Agrarian University of the North Ural, 625003 Tyumen, Russia
}

\begin{abstract}
Agricultural land management should aim to ensure balance and sustainable development of the agro-industrial complex. When using land to the owner of this resource a number of important requirements are made: investment in agricultural production, increasing the number of jobs, the use of advanced agroindustrial technologies, the creation of an effective management and marketing system. The use of land shares lies in the fact that due to the lack of demand for a large number of agricultural land, there are significant losses of agricultural products, which leads to the non-receipt of land payments to municipal budgets.
\end{abstract}

\section{Introduction}

The rules of the Civil Code of the Russian Federation apply to transactions with shares in the common ownership right to a land plot from agricultural land. B If the number of participants in the shared ownership of land plot from agricultural lands exceeds five, the rules of the Civil Code of the Russian Federation are applied taking into account the features established by this article, as well as articles 13 and 14 of the Federal Law of 24.07.2002 № 101 "On turnover of agricultural land" [1].

An unclaimed land share may be recognized as a land share owned by a citizen who has not leased this land share or otherwise disposed of it for three or more years in a row. At the same time, land shares, the rights to which are registered in accordance with the Federal Law of July 13, 2015 № 218-FZ "On State Registration of Real Estate", may not be recognized as unclaimed land shares on the grounds specified in this paragraph [2].

Unclaimed land share may also be recognized as a land share, the information about the owner of which is not contained in the decisions of local governments on the privatization of agricultural land adopted before the date of entry into force of the Federal Law of July 13, 2015 N 218-FZ "On State Registration of Real Estate", or land share, the owner of which died and there are no heirs both under the law and the will, or none of the heirs has the right to inherit, or all the heirs are removed from the inheritance, or none of us.

The local government body of the settlement or city district at the location of the land plot, which is in shared ownership, publishes a list of unclaimed land shares in the media, determined by the subject of the Russian Federation, and places on its official website on the
Internet (if any) not less than three months prior to the convening of the general meeting of participants in the share ownership. The said list shall also be placed on information boards located on the territory of the municipality in question.

The list of unclaimed land shares shall be submitted by the local self-government body of the settlement or city district at the place of location of the land plot owned by the share, for approval by the general meeting of participants of the share ownership.

People who consider that they or their land shares are unreasonably included in the list of unclaimed land shares are entitled to submit objections in writing to the local self-government body of the settlement or city district at the location of the land plot being in shared ownership, and to declare it at the general meeting of participants of the share ownership, which is the basis for excluding these persons and (or) land shares from the list of unclaimed land shares.

From the date of approval of the list of unclaimed land shares by the general meeting of participants in the share ownership of land shares, information on which is included in the specified list shall be recognized as unclaimed.

If the general meeting of participants of share ownership within four months from the date of publication of the said list has not made a decision on the issue of unclaimed land shares, the local government body of the settlement or city district at the location of the land plot, which is in share ownership, has the right to approve such a list independently [3].

The body of local self-government of a settlement or an urban district at the location of the land plot, which is in shared ownership, has the right to apply to the court with the requirement to recognize the right of municipal

Corresponding author: Evtushckova17@yandex.ru 
ownership of land shares, recognized in an order established by this article as unclaimed.

As of today, the use of agricultural lands is not carried out in full, therefore, it can be assumed that a large number of areas cease to participate in agrarian production.

Thus, this methodology will contribute to the rational use of agricultural land in the right of common ownership.

To date, not all shareholders in the Tyumen Oblast have used the ownership right to their land shares. As a result of non-use of land for three years or more it is recognized as unclaimed. The object of the study is the agricultural land of the Tyumen Oblast, which is in common ownership of citizens [4].

\section{Results and discussion}

Berkutsk municipality is located in the southwest of Yalutorovskiy district (figure 1).

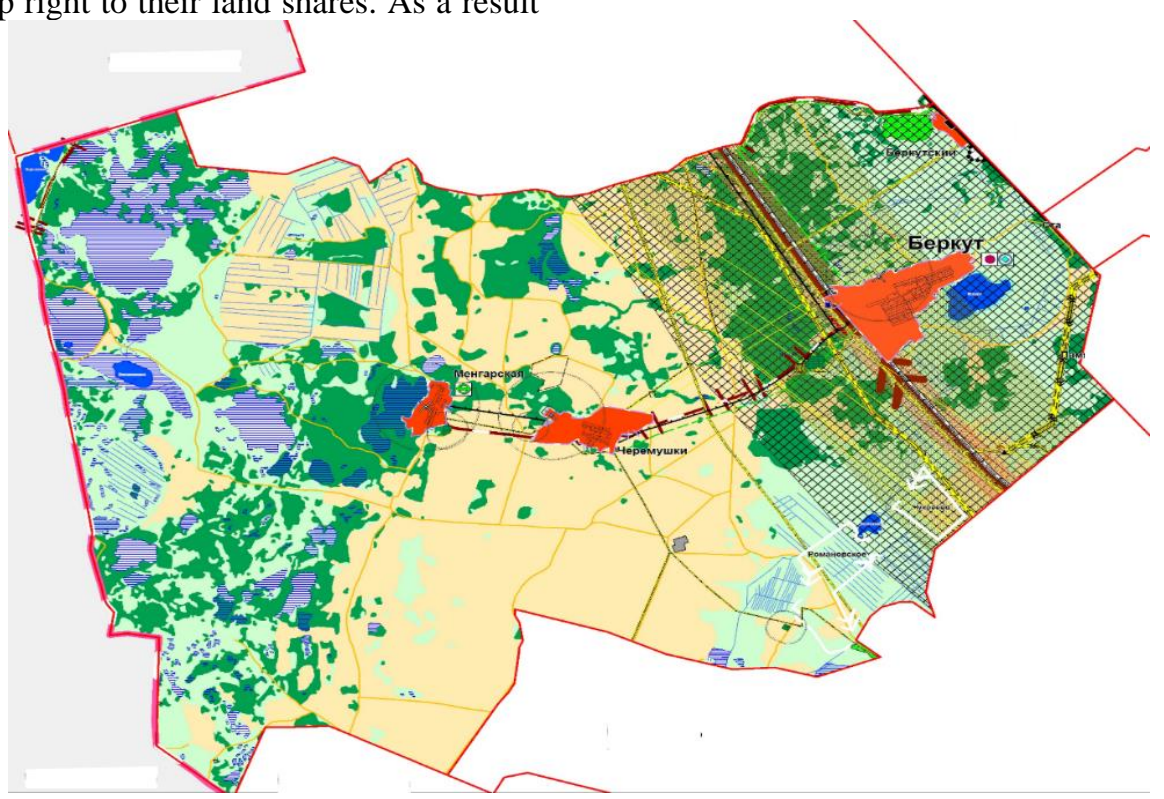

Fig. 1. Berkutovsky Municipality Master Plan

The territory of the village is crossed by the sections of the Tyumen-Yalutorovsk-Ishim-Omsk federal highway and the Trans-Siberian Railway, which include the rural settlement in the area of influence of the international transport corridor "West-East". In addition, the relative proximity to the district center (Yalutorovsk city) determines the relatively favorable conditions for further development.

The area of the rural settlement occupies 21800,411 hectares, where about 1.4 thousand people live. The municipality includes 3 settlements: Berkut, Cheremushki and Mengarskaya.

The territory of the Agricultural Cooperative LLC "Siberia" includes 3 settlements: Berkut settlement, Cheremushki settlement, Mengarskaya settlement. Mengarskaya and Cheremushki villages.

The total area of the agricultural cooperative "Siberia" LLC is 21,200 hectares, including agricultural lands 13795.71 (Table 1).

The largest area is occupied by agricultural lands $65 \%$ of the total area of the territory, of which arable land $-36.2 \%$, fodder lands $-17 \%$, hayfields $-11.2 \%$ and perennial plantations $-0.6 \%$, the smallest under water objects $-0.7 \%$.

The analysis of the existing organization of land use in the agricultural cooperative "Siberia" LLC (1990) includes data on the formation of a fund of land redistribution, information on the lands of the rural administration, peasant farm, the organization of the territory of arable land, hayfields and pastures, as well as land of general use.

The total area of lands of the Yalutorovsky district included in the state cadastral registration is 47.7 thousand hectares, of which 3 thousand hectares are unclaimed land shares (Table 2).

Table 1. Distribution of the Rayon Land Fund by Land

\begin{tabular}{|c|l|c|c|}
\hline No. n/a. & Category of land, land & Square, ha. & $\%$ \\
\hline 1 & Total area & 21,200 & 100 \\
\hline 2 & Total farmland, including & 13795.71 & 65 \\
& - arable land & 7687.34 & \\
& - perennial plantings & 125.88 & \\
& - fodder lands & 3598.81 & \\
& - deposit & - & \\
& - hayfields & 2383.68 & \\
\hline 3 & Forest areas & 4713.71 & 22.2 \\
\hline 4 & Woody shrub vegetation & - & - \\
\hline 5 & Swamps & 1792.75 & 8.5 \\
\hline 6 & Waterbodies & 140.93 & 0.7 \\
\hline 7 & Building lands & 520.1 & 2.4 \\
\hline 8 & Roads & 236.8 & 1.2 \\
\hline
\end{tabular}

The Administration of the Yalutorovskiy District of the Tyumen Oblast, in accordance with Article 12.1 of the Federal Law of 24.07.2002 No. 101-FZ "On Turnover of Agricultural Lands", has compiled a list of unclaimed land shares of the former LLP "Siberia", the average land share size of 10.17 hectares, the cadastral value of land shares that are on the right of common ownership varies from 42.051.0 to 735.892 .5 rubles. 
The total area of unclaimed land shares on the territory of the agricultural cooperative "Siberia" LLC is 5920 hectares.

Table 2. Unclaimed land shares in municipal areas of the Tyumen Oblast as of January 1, 2016

\begin{tabular}{|c|c|c|c|c|}
\hline $\begin{array}{l}\text { Municipal } \\
\text { area }\end{array}$ & 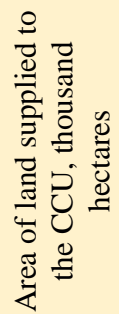 & 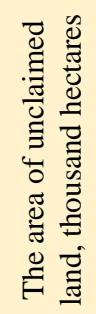 & 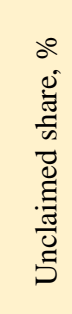 & 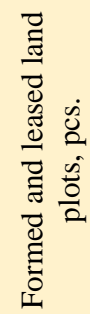 \\
\hline Abatsky & 100.9 & 31.2 & 30.9 & 407 \\
\hline Armizonian & 90.6 & 2.1 & 2.3 & - \\
\hline Aromashevskiy & 59.2 & 9.4 & 15.9 & 559 \\
\hline Berdyuzhskiy & 56.7 & 5.3 & 9.3 & 94 \\
\hline Vagayskiy & 74.3 & 14.8 & 19.9 & - \\
\hline Vikulovskiy & 61.2 & 5.5 & 9.0 & - \\
\hline Golyshmanovskiy & 109.0 & 4.7 & 4.3 & 171 \\
\hline Zavodoukovskiy & 70.0 & 1.0 & 1.4 & 31 \\
\hline Isetian & 86.1 & 7.0 & 8.1 & - \\
\hline Ishimskiy & 181.8 & 19.9 & 10.9 & 470 \\
\hline Kazanskiy & 113.7 & 5.8 & 5.1 & 75 \\
\hline Nizhnetavdinskiy & 54.2 & 6.7 & 12.4 & - \\
\hline Omutinskiy & 50.0 & 6.6 & 13.2 & - \\
\hline Sladkovskiy & 154.9 & 49.7 & 32.1 & 1604 \\
\hline Sorokinskiy & 76.9 & 53.5 & 69.9 & 1268 \\
\hline Tobolskiy & 65.8 & 12.3 & 18.7 & - \\
\hline Tyumenskiy & 72.4 & 1.7 & 2.3 & - \\
\hline Uvatskiy & 100.4 & 30.2 & 30.1 & - \\
\hline Uporovskiy & 103.0 & 11.3 & 11.0 & 341 \\
\hline Yurginskiy & 45.7 & 8.1 & 17.1 & 202 \\
\hline Yalutorovskiy & 47.7 & 3.0 & 6.3 & - \\
\hline Yarkovskiy & 74.2 & 3.7 & 5.0 & $\begin{array}{c}- \\
-\end{array}$ \\
\hline Total and average & 1848.7 & 245.5 & 15.2 & 5222 \\
\hline
\end{tabular}

Within three months from the date of publication of the list, persons who believe that they or their land shares are unreasonably included in the list of unclaimed land shares, have the right to submit written objections to the Administration of the Berkutsk rural settlement of Yalutorovskiy district, and to declare it at the general meeting of participants of the share ownership, which is the basis for exclusion of these persons and (or) land shares from the list of unclaimed land shares.

In legal terms, the largest share is occupied by the land shares used on the basis of the ownership right $(85 \%)$, land shares used without allocation in kind $(99 \%)$.

A total of 7,213.87 hectares are collectively owned.

According to the list presented by the Yalutorovskiy inter-district department of the Rosnedvizhimost' Administration of the Tyumen Region, the number of collective and joint ownership participants located within the boundaries of the agricultural cooperative "Siberia" LLC is 701 .

\section{Conclusion}

On the basis of the obtained data on the use of agricultural land collectively owned by the agricultural cooperative Sibir LLC, the following analysis is presented in this paper: composition and use of land shares; availability of unclaimed land shares, delivered and not delivered to the Civil Code of Ukraine land plots; size of rural settlements by area of agricultural land.

Land shares delivered to the CCU are 1293.87 hectares, and 5920 hectares were not registered.

The size of the land share in the agricultural cooperative Siberia LLC is influenced by the composition and ratio of lands, as well as the number of population entitled to receive the land share.

To date, the owners of land shares in the Tyumen Oblast have disposed of them as follows:

- was leased out (42.5\%);

- transferred the right to use the land share in the authorized capital of an agricultural enterprise $(15.2 \%)$;

- are used for private subsidiary farming $(7.2 \%)$;

- transferred the land share directly to the charter capital of the agricultural enterprise (4.2\%);

- $14.9 \%$ of farmers did not dispose of their land shares in any way;

- $16 \%$ of unclaimed shares.

The percentage of unclaimed land on the territory of the agricultural cooperative Siberia LLC was $27.9 \%$.

Analysing the data, the problem of unclaimed land shares in the Tyumen region is confirmed. The reform of collective enterprises has not been completed, so the unclaimed land shares are held by collective enterprises, which have not been legally liquidated, but actually do not carry out financial and economic activities. There are 164 agricultural enterprises in the Tyumen Oblast that have ceased to exist due to bankruptcy, but for which the issue of termination of land rights has not been resolved. There are 819 thousand hectares of lands under the state acts [5].

It should be concluded that large-scale land reclamation works have not led to the expected result of including land as an active factor in the development of the country's economy. In the area of land use, there are many problems related to land use:

Delimitation of state ownership of land;

The boundaries of administrative-territorial formations;

- re-registration of land plots under privatized objects into ownership or lease;

- withdrawal of lands from agricultural turnover;

- reasonable transfer of lands from one category to another;

- threatening dimensions of land degradation, etc.

The analysis of the state of use of agricultural land on the territory of the agricultural cooperative Siberia LLC confirms to a greater or lesser extent the relevance of the survey: 
- not only inventory of land shares, but also a comprehensive inventory of all lands within the boundaries of agricultural land use;

- development of landscape and environmental zoning schemes;

- monitoring of land and land shares, as it is currently difficult to operate with data from agricultural land management projects and to form a model of land and property complex of agricultural land use for sustainable development.

When analysing the use of land shares on the territory of the agricultural cooperative "Siberia" Ltd. and considering the procedure of allocation of land plots in respect of land shares, some problems have been identified, based on which the following solutions are proposed:

- Organization of land monitoring at the municipal level to identify unclaimed land shares.

- Carrying out works on complex inventory of agricultural lands and their assessment, which will allow to determine the degree of suitability of lands for agricultural production.

- Due to the complexity of the complex of work on the allocation of land plots in terms of land shares, it will be expedient to directly participate and assist local authorities in the organization of this procedure, as well as the development of specific maximum prices for the execution of works in the preparation of the project of surveying at the level of the subjects of the Russian Federation.

- Development of complex land management projects for redistribution of land in rural settlements (before the drafting of land surveying projects) to create favorable spatial conditions and placement of engineering infrastructure. In order to ensure the rational use of land resources, it is necessary to oblige land users to submit a long-term business plan based on the onfarm land management project.

\section{References}

1. Federal law no. 101-FZ "On the turnover of agricultural land" (2002)

2. Federal law no. 218-FZ "On state registration of real estate" (2015)

3. S. Lipski, The increase the fertility of agricultural land and monitoring of this land are the necessary conditions for ensuring food security, Russ. J. of Agricult. and Soc.-Econ. Sci., 25(1), 3-7 (2014)

4. N.A. Dolgikh, E.P. Evtushkova, The current state and use of land shares in the right of common ownership of agricultural land in the south of the Tyumen region, In proc. of Int. Stud. Sci. and Pract. Conf. "Actual Issues of Science and Economics: New Challenges and Solutions," 37-39 (2017)
5. S.A. Galchenko, Economic efficiency of the system of state land cadastre of administrative-territorial entities (Moscow, 2003)

6. E.P. Evtushkova, T.V. Simakova, L.N. Skipin, Analysis of the use of land shares in the right of common ownership on agricultural land in the south of the Tyumen region, Russ. Agricult. policy, 7(67), 81-84 (2017)

7. Law of the Tyumen region 03.11.2003 №. 170 “On the utilization of agriculture land"

8. P.F. Loyko, Land utilization: Russia, world (Future prospective) (State University of Land Management, Moscow, 2009)

9. P.F. Loyko, Improving the land use management system and developing the territorial cadastre in the Russian Federation, J. Proper. Relat. in the Russ. Feder., 3, 6-18 (2012)

10. M.A. Sulin, Land management (Kolos, Moscow, 2009)

11. Federal law (2002) № 7-FL «On environmental protection».

12. T.V. Papaskiri, V.I. Nilipovsky, The use of innovative technologies in land use planing education, E\&M Euroeducat., 2-3, 27-32 (2009)

13. S. Lipski, State regulation of the agricultural land market in modern Russia, Stiinta Agricola, 1, 123-129 (2014)

14. S.A. Lipski, Private ownership for agricultural lands: advantages and disadvantages (experience of two decades), Stud. on Russ. Econ. Developm., 26(1), 63-66 (2015)

15. V.V. Vershinin, A.A. Murasheva, V.A. Shirokova et al., The solutions of the agricultural land use monitoring problems, Int. J. of Environm. and Sci. Ed., 11(12), 5058-5069 (2016)

16. Z. Gebeltová, H. Rezbová, D. Pletichová, Quantification of changes in the state of the CR agricultural land fund from 2001-2013, Agris OnLine Papers in Econ. and Inform., 6(3), 13-25 (2014)

17. V.I. Makeeva, Assessment of Soil Tolerance for Compaction and Vertisolization in the South of European Russia, Eurasian Soil Sci., 38(2), 205-211 (2005)

18. A.N. Ratnikov, P.M. Sapozhnikov, N.I. Sanzharova et al., Cadastral Valuation of Land Contaminated with Radionuclides, Eurasian Soil Sci., 49(1), 116-124 (2016)

19. A.S. Yakovlev, E.N. Molchanov, O.A. Makarov et al., Regulatory and Legislative Aspects of the Ecological Evaluation and Control of Soil Degradation in Russia on the Basis of the Assessment of soil Ecological Functions, Eurasian Soil Sci., 48(9), 991-996 (2015) 